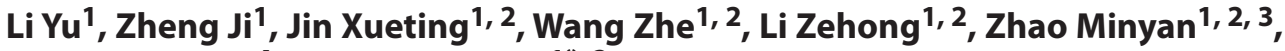 Huang Yongbin ${ }^{4}$, Dong Suocheng ${ }^{1 *}, 2$
}

${ }^{1}$ Institute of Geographic Sciences and Natural Resources Research, Chinese

Academy of Sciences, 11A, Datun Road, Chaoyang District, Beijing, People's

Republic of China, 100101

* Corresponding author: e-mail: dongsc@igsnrr.ac.cn

2 University of Chinese Academy of Sciences, 19 A Yuquan Rd, Shijingshan District, Beijing, People's Republic of China, 100049

3 Faculty of Ecotourism, Southwest Forestry University, 300, Bailong Road, Kunming, People's Republic of China, 650224

${ }^{4}$ School of Economics, Anhui University of Finance \& Economics, Hefei, Anhui,

People's Republic of China, 230029

\section{INTEGRATED ASSESSMENT \\ OF INVESTMENT ENVIRONMENT \\ AND ACTIONS FOR THE “BELT AND ROAD" COUNTRIES}

\begin{abstract}
The Silk Road Economic Belt" and "the 21st-Century Maritime Silk Road" initiative aims at promoting regulated flow of economic factors, allocating resources efficiently, integrating markets, and developing a broader, higher, and deeper level of regional interaction to create an open, inclusive, balanced, and widely beneficial regional economic cooperation framework. Comprehensive and objective assessment and research on investment-climate geopolitical strategy of the countries in the "Belt and Road" zone would help improve security and stability of China's foreign economic and trade exchanges along with its political and economic influence. Based on Delphi technique, the investment environment evaluation system of the "Belt and Road" countries has been developed and used to comprehensively analyze social and economic development, traffic infrastructure, informatization, resources, and political and security environment, all of which are the important conditions for investment environment of the "Belt and Road" countries. The results show that Russia, Mongolia, Pakistan, Central Asia, Germany, Netherlands, Italy, and Hungary represent the attractive investment areas. Eastern Europe, India, and Iran represent the key investment areas. Based on the analysis, investment strategy steps for the "Belt and Road" countries have been formulated. We hope our research can provide the scientific foundation for decision-making in China in relation to the "Belt and Road" foreign investment strategy.
\end{abstract}

KEY WORDS: the Belt and Road, investment environment, actions.

CITATION: Li Yu, Zheng Ji, Jin Xueting, Wang Zhe, Li Zehong, Zhao Minyan, Huang Yongbin, Dong Suocheng (2017) Integrated assessment of investment environment and actions for the "Belt and Road" countries. Geography, Environment, Sustainability (GES Journal), Vol. 10, No 1, p. 21-33.

DOI: 10.24057/2071-9388-2017-10-1-21-33 


\section{INTRODUCTION}

The National Reform Development Commission, the Ministry of Foreign Affairs, and the Ministry of Commerce have issued the joint statement (that coincided with the Boao Forum for Asia [27 March 2015 Hainan]) "Vision and action plan to promote the joint creation of "The Silk Road Economic Belt" and "the 21 st-Century Maritime Silk Road." The document stressed that the "Belt and Road" strategy is aimed at promoting free but managed mobility of economic factors, the efficient allocation of resources, deeper market integration, and joint development of balanced, favorable for all participants, architecture of regional economic cooperation [Vision and action, 2015]. Together with other countries, the implementation of the "Belt and Road" initiative should become a key element of China's "moving outward" policy proclaimed by its government at a new phase of globalization.

However, with the strengthening of the economic power of the country and the increase of Chinese investments abroad, there is a growing concern worldwide associated with the extent of investments of Chinese companies, which can exacerbate restrictive measures and numerous inspections of Chinese investors. Most of Chinese investments abroad go to developing countries of Asia, Africa, and Latin America. In some countries, the political situation is unstable. Competition for the use and development of resources is growing. Investment attraction policy changes often and there are large differences between individual countries. Relationships between the investors and the local population are not always favorable. There are other factors that increase the risks to Chinese enterprises investing abroad. At the same time, some Chinese investors are not fully aware of the investment climate in various countries. Therefore, Chinese investments in the "Belt and Road" countries should be based on a comprehensive scientific foundation [Liu, 2015].

The goal of this paper is to provide an objective assessment of investment environment in the "belt" countries to establish the scientific substantiation for Chinese foreign investment decision-making in the course of implementation of the "moving outward" strategy.

\section{A SYSTEM OF INDICATORS FOR ASSESSING THE INVESTMENT ENVIRONMENT OF THE "BELT AND ROAD" COUNTRIES}

In 1968, American scientists I. Litvak and P. Banting first proposed the concept of "investment environment" and theoretically justified it. Investment environment is defined as the "external conditions, including material and immaterial environment" [Li, 1993]. The investment environment is also called the investment climate, i.e., a complex of all necessary conditions and requirements for construction projects and business activities [Chinese Encyclopedic..., 1999]. Actually, investment environment is a complex set of favorable or unfavorable conditions and factors that have a direct or indirect impact on the investment in a particular area, e.g., geographical location, natural resources, infrastructure, availability of raw materials, level of market development, competition, human resources, information channels, finance circulation, tax burden, social services, economic policy, applicable law, social order, and political situation. Thus, the investment environment covers all aspects of public life: economy, politics, culture, and law, including the physical and geographical conditions, infrastructure, information, and policies in a country [Wu, 2002].

Since the 1960s, in China and abroad, a number of studies to assess the environment for foreign investment have been conducted. Among the main approaches discussed, are a comparative analysis of "cold" and "warm" countries [Litvak, Banting, 1973], ranking factors that determine the investment environment in accordance with their weights [Stobaugh, 1969], including by means of multivariate and principal component analyses [Jian et al., 1987], and assessment of investment risks in different countries 
[Robock, 1971]. In recent years, the main directions in the investment environment evaluation have been established. Research was primarily aimed at the optimization of the parameters and methods. Thus, D. Kaufman et al. [1999] used six parameters; S. Goberman and D. Shapiro [2002] relied on such complex variables as indices of human development (human development index), management, environmental sustainability (environmental sustainability index), and regulatory load.

In this paper, the investment environment assessment of the "belt" countries is brocken into six sections: socio-economic, transport infrastructure, informatization, strategic resources availability, political situation, and security. The level of socio-economic development assumes the combination of such factors as the size of the economy (GDP), its growth rate, and GDP per capita. Transport infrastructure includes engineering objects, used for the organization of public transport, that provide public services of goods and people transport for public production and livelihoods of the population. Infrastructure development generates a "multiplier effect," that is, it can be several times more effective than the share of investments for these purposes in the aggregate demand and national income. Infrastructure represents the important basis for the long-term and stable growth of the national or regional economy. Informatization level is now a major, after GDP, comprehensive indicator of the economic strength of the country. It can be assessed by a general index, reflecting the availability of information resources, development of information networks, use of information technology, production of information products and services, availability of informatization personnel, informatization development environment, etc, overall, by six groups of 20 indices. Some authors figuratively name this index the "national IQ" (NIQ). Strategic resources is a term for labor and resources, both natural and man-made, that play an important role in the event of war. Availability of strategic resources depends on the geographical location of the country, the size of its territory, the size and quality of the population, topography, and subsurface resources structure, along with rational development potential, transportation, storage, distribution, and consumption of resources. Strategic resources represent an important factor in the national economic and military strategy. The political situation is a political background at a certain period in a country or region, reflecting various factors such as the frequency of change of government, political agenda's stability, etc. The national security factor encompasses external political, economic, and military conditions affecting the security of the country. They may be of global, regional, or peripheral character. Security environment reflects the national interest, the situation in the country, and the state of intergovernmental relations.

\section{INTEGRATED ASSESSMENT OF INVESTMENT ENVIRONMENT}

\section{The level of socio-economic development}

Development of the "Belt and Road" countries is very uneven in terms of the total amount of gross domestic product (GDP) and GDP per capita, the number of population, the state's expenditures (in \% of GDP), and exports and imports of goods and services (in \% of GDP). All these data were taken from the World Bank database. In 2013, these countries were divided into several groups. The group with the highest levels of social and economic development included Russia, Germany, Saudi Arabia, India, Malaysia, and Indonesia. The next group included Kazakhstan and Iran. The lowest level included five Central Asian countries (Fig. 1).

\section{Transport infrastructure}

Four parameters, i.e., roads, railways, ports, and air transport, were used to assess transport infrastructure with the help of the data from the "Global Competitiveness Report 2014-15" published by World Economic Forum [http://reports.weforum.org/globalcompetitiveness-report-2014-2015/] Each 


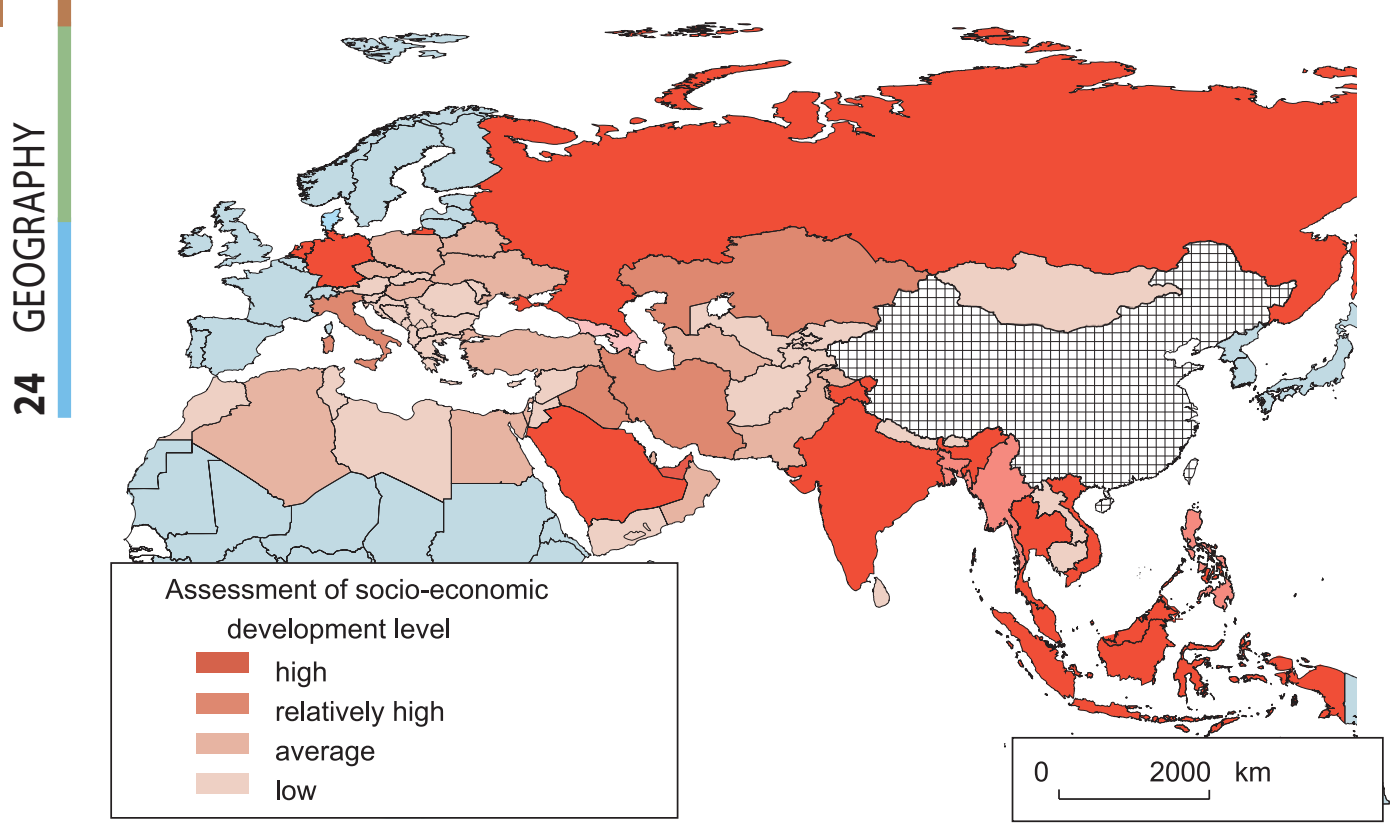

Fig. 1. Spatial distribution of the "Belt and Road" countries by level of socio-economic development in 2013

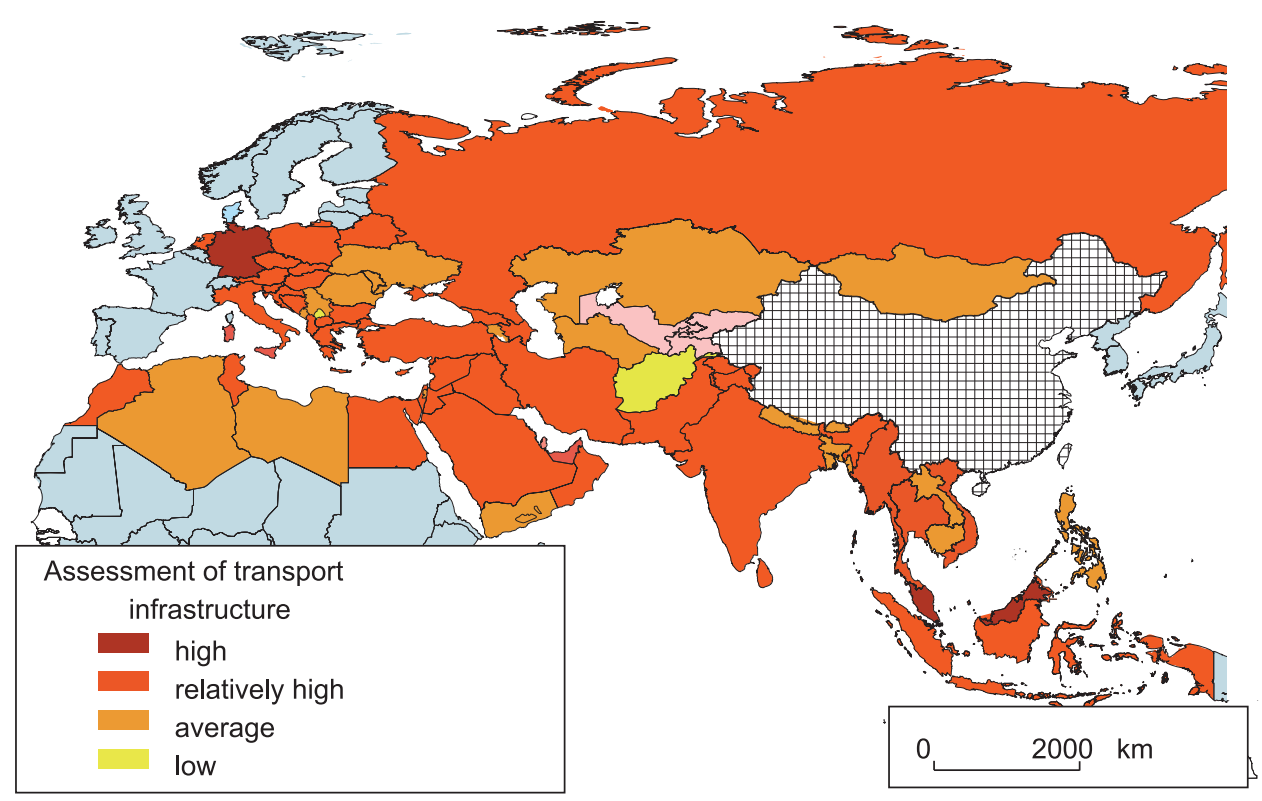

Fig. 2. Spatial distribution of the "Belt and Road" countries by level of transport infrastructure development in 2013 
indicator was converted to a comparable form by its ranking on a scale from 1 to 10 , 1 being the lowest score. Furthermore, all normalized indicators were summarized with the following weights: 0.6 for marine transport, 0.2 for air transport, and 0.1 each for highways and railways. The smaller the final value, the lower is the level of development of transport infrastructure. Northern and many southern "Silk Road Economic Belt" countries (Germany, the United Arab Emirates, Malaysia, Russia, the majority of countries in West Asia, Eastern Europe, South, and South-East Asia) were characterized by a relatively high level; five Central Asian countries had low level. Eastern Europe and Mongolia occupied the intermediate position (Fig. 2).

\section{Informatization level}

Two parameters were used to assess informatization level: the number of mobile phones and internet-users per 100 persons. This information was drawn from the World Bank database. These parameters for each country were normalized from 1 to 10. Their average values represented countries' informatization level indices. Fig. 3 shows that the values decreased from west to east. Germany is the country with the highest level of informatization; it is also relatively high in Russia, Kazakhstan, Saudi Arabia, Malaysia, and some countries of Eastern Europe. Informatization of the countries of Western, Central, and South Asia is average or low.

\section{Availability of strategic resources}

Evaluation of availability of strategic resources was conducted for five types: energy, arable land, forestry, food, and water, based on the World Bank data. Specific indicators included arable land area, forest area, renewable freshwater resources per capita, and proven oil reserves. After normalization of separate parameters for calculating the degree of the overall availability, average values were calculated. Countries rich in strategic resources included Russia, Eastern

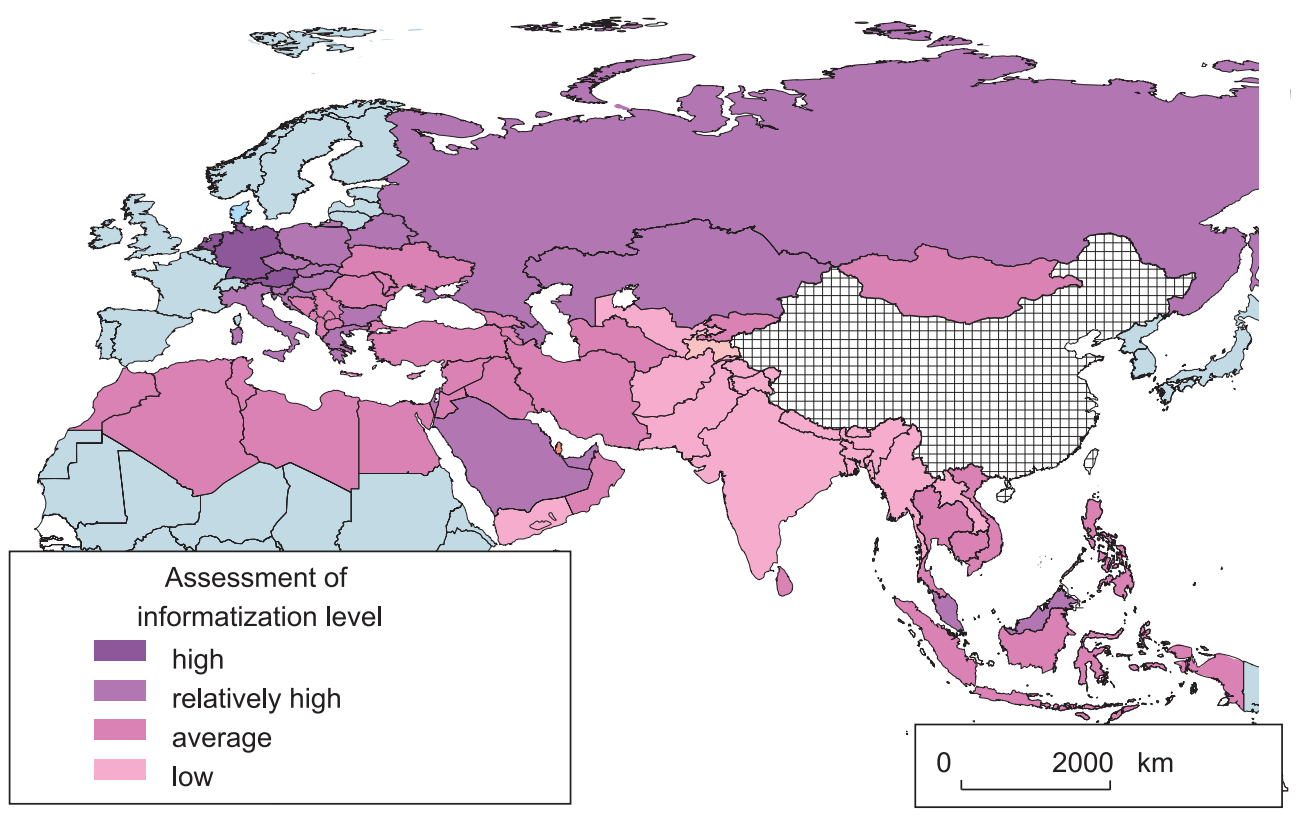

Fig. 3. Spatial distribution of the "Belt and Road" countries by level of informatization in 2013 


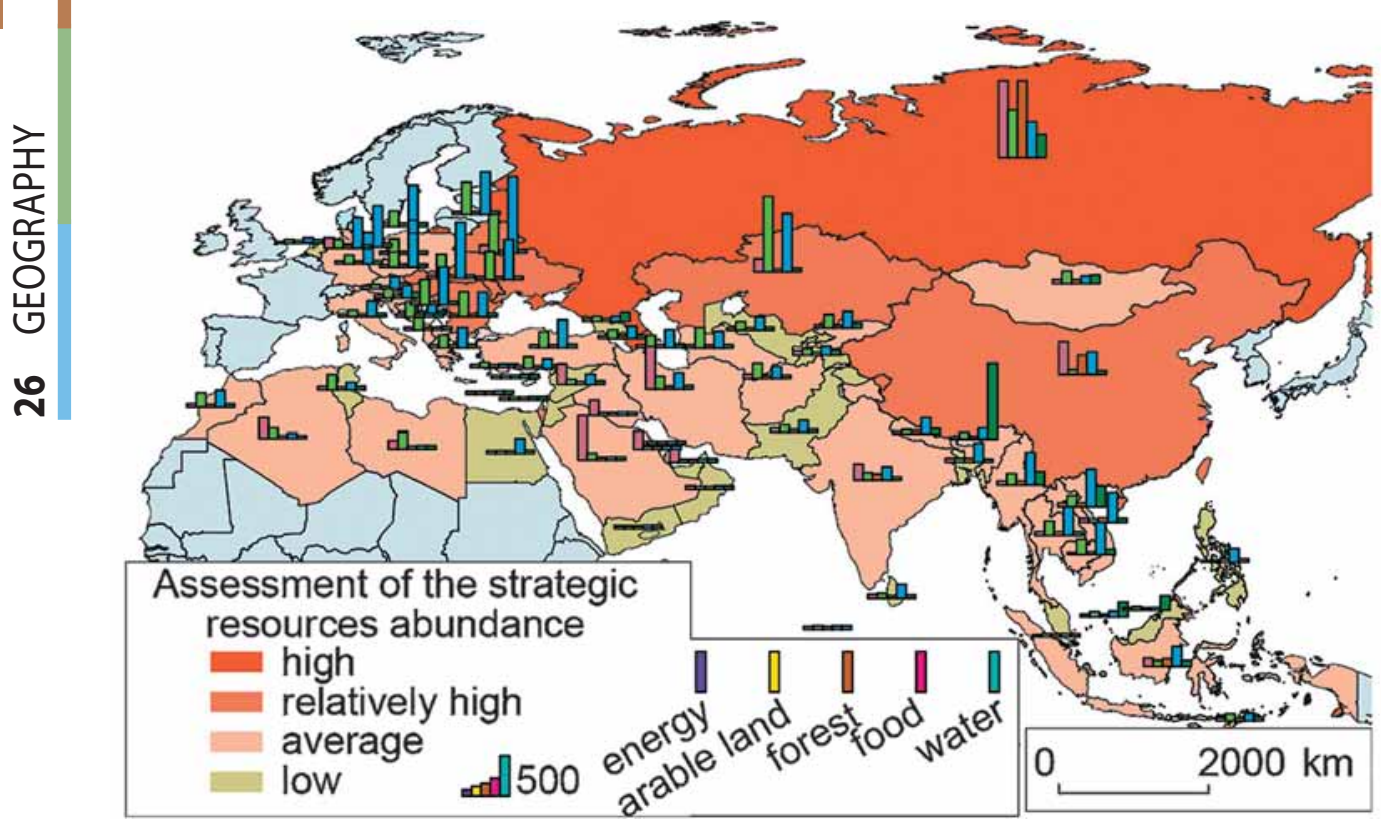

Fig. 4. Spatial distribution of the "Belt and Road" countries by level of strategic resources availability in 2013

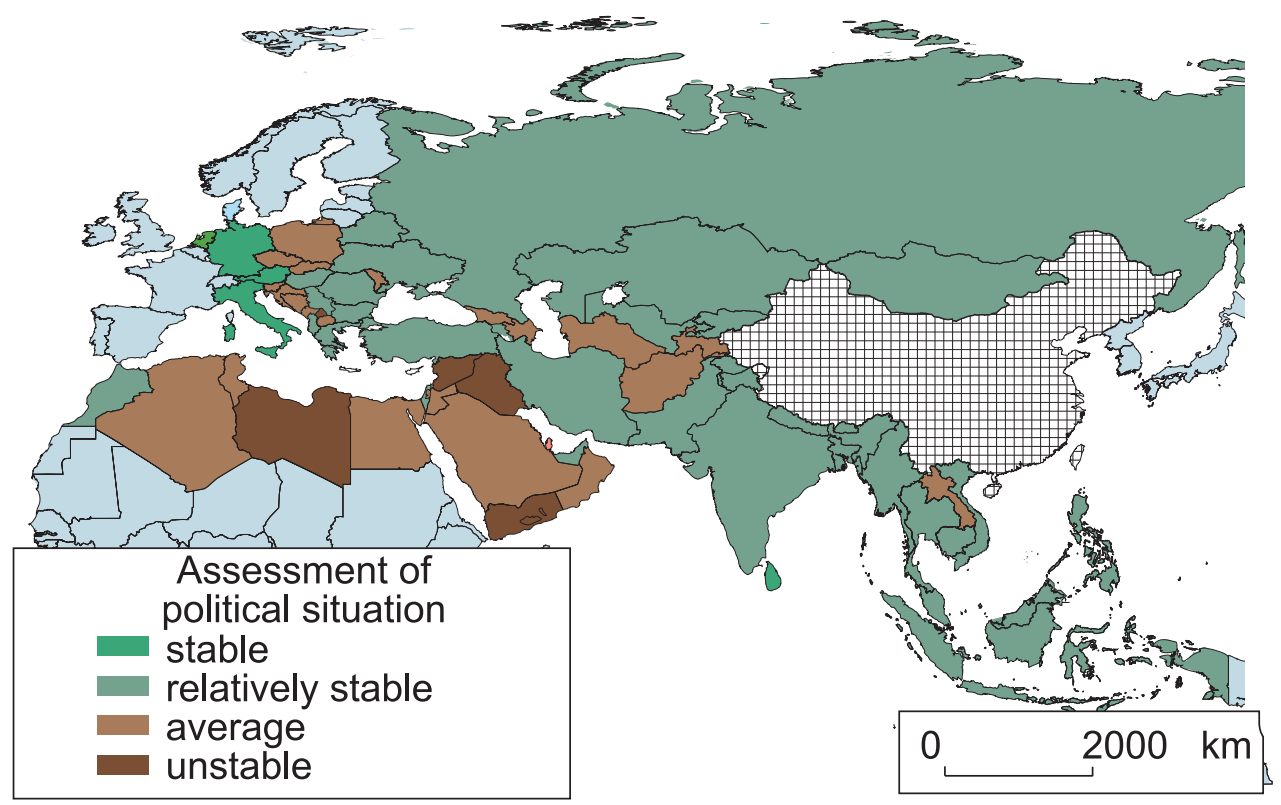

Fig. 5. Spatial distribution of the "Belt and Road" countries by political situation in 2013 
Europe, Central Asia, Kazakhstan, and the Middle East. Russia is the richest "Belt and Road" country: its total index is much higher than in other countries (Fig. 4).

\section{The political situation}

Political situation in the "Belt and Road" countries was assessed based on the summarized results of the evaluation of indices of policy, the perception of corruption (The Corruption Perceptions Index), and the rule of law (The Rule of Law Index). It appeared that stable situation exists in the countries of Western Europe and Russia. Relatively stable regions include Central Asia, Eastern Europe, and Southeast Asia. Syria, Iraq, Yemen, and Libya are countries with unstable political situation (Fig. 5).

\section{Security environment}

Assessment of security was based on terrorism index for individual countries in 2014. "Secure" countries are concentrated in Europe and Central Asia, including
Mongolia. Afghanistan, Pakistan, India, Syria, Iraq, and Yemen are considered hazardous (Fig. 6).

\section{THE INVESTMENT STRATEGY IN THE "BELT AND ROAD" COUNTRIES}

The assessment based on Delphi technique allowed us to determine the weights of all parameters to calculate the integral index: economic and social development, transport infrastructure, information technology, availability of strategic resources, political situation, and security. They were, respectively, $0.2,0.15,0.15,0.2,0.15$, and 0.15 . The weighted indices were summed. The "Belt and Road" countries were divided into the priority, key, and potential investment and risk zones based on the values of the integral index (Table 1, Fig. 7).

Russia, Mongolia, Pakistan, five countries of Central Asia, and European countries (Germany, Netherlands, Italy, and Hungary) were included in the priority investment zone; countries of Eastern Europe, India, Iran, and several other countries were included in the key zone.

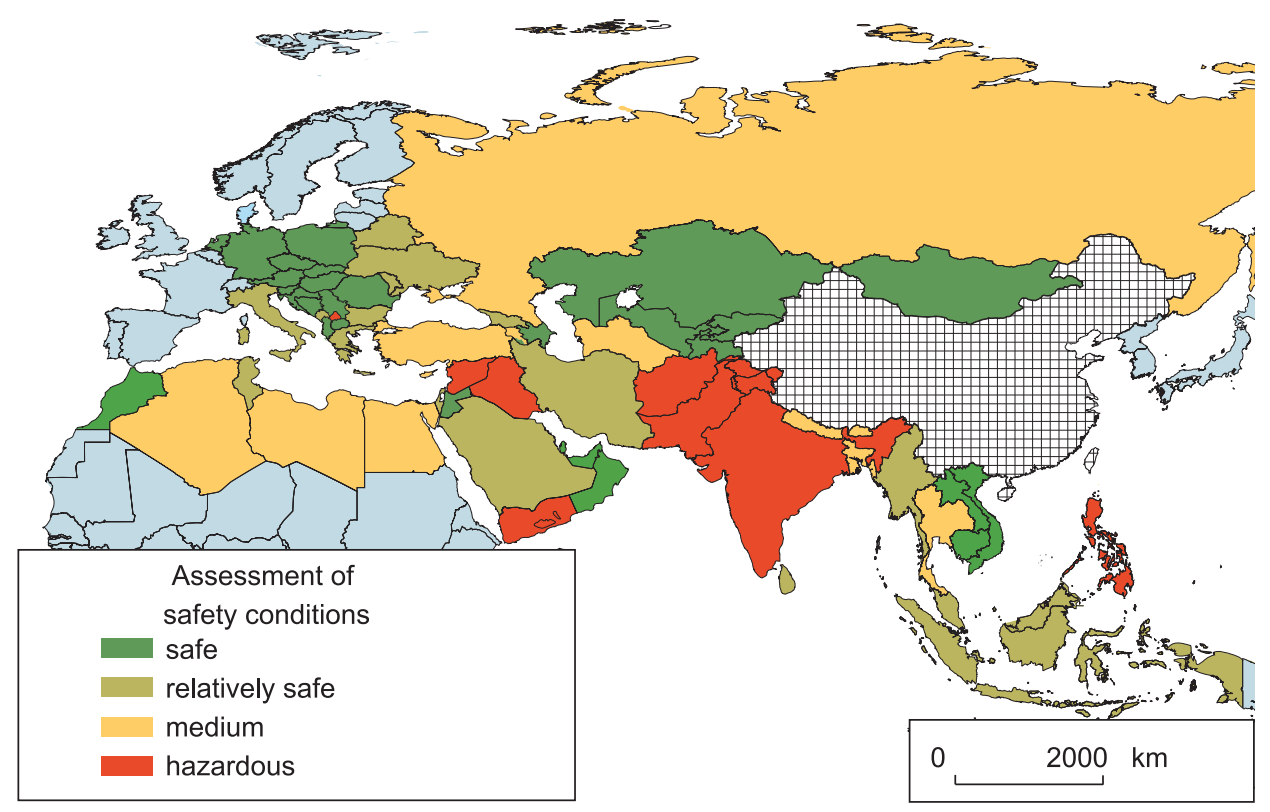

Fig. 6. Spatial distribution of the "Belt and Road" countries by security in 2013 
خ্ণ

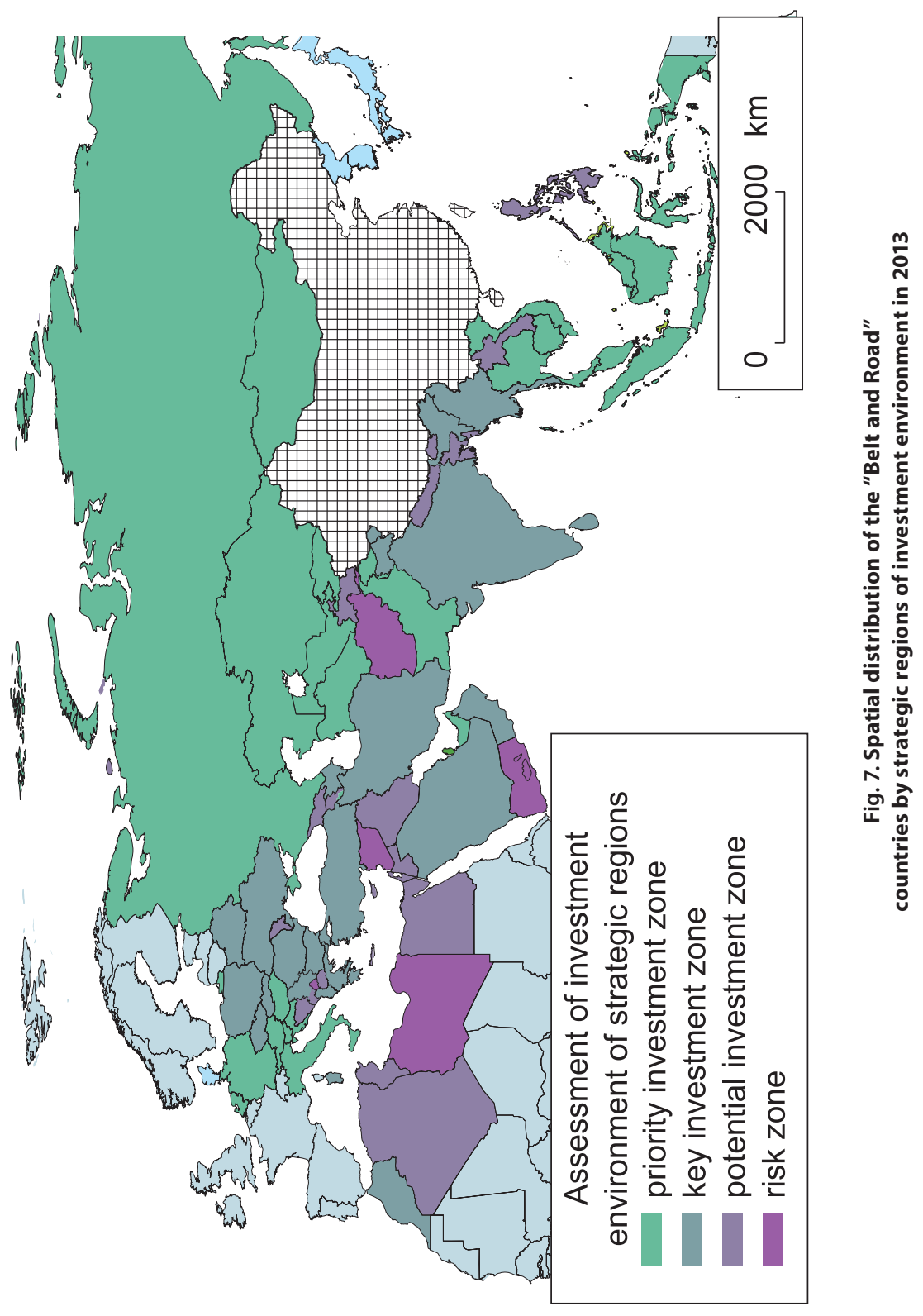


Table 1. The grouping of the "Belt and Road" countries by the integral index of investment environment

\begin{tabular}{|l|l|l|l|}
\hline \multicolumn{1}{|c|}{ Asia } & \multicolumn{1}{c|}{ Europe } & Africa \\
\hline $\begin{array}{l}\text { Priority invest- } \\
\text { ment zone }\end{array}$ & $\begin{array}{l}\text { Pakistan, Kazakhstan, Turk- } \\
\text { menistan, Kyrgyzstan, Uzbekistan, } \\
\text { Malaysia, Thailand, Singapore, } \\
\text { Vietnam, the United Arab Emir- } \\
\text { ates, Indonesia, Mongolia }\end{array}$ & $\begin{array}{l}\text { Russia, the Netherlands, Germany, Aus- } \\
\text { tria, Italy }\end{array}$ & \\
\hline $\begin{array}{l}\text { Key investment } \\
\text { zone }\end{array}$ & $\begin{array}{l}\text { SaudiArabia, Iran, Qatar, Cambo- } \\
\text { dia, Myanmar, Israel, Oman, Ku- } \\
\text { wait, Bhutan, SriLanka, India }\end{array}$ & $\begin{array}{l}\text { Ukraine, Hungary, Poland, Serbia, Turkey, } \\
\text { Czech Republic, Croatia, Slovakia, Slove- } \\
\text { nia, Romania, Bulgaria, Belarus Albania, } \\
\text { Greece, Azerbaijan, Armenia }\end{array}$ & Morocco \\
\hline $\begin{array}{l}\text { Potentialinvest- } \\
\text { ment zone }\end{array}$ & $\begin{array}{l}\text { Tajikistan, Bahrain, Maldives, Ne- } \\
\text { pal, Lebanon, the Philippines, Laos, } \\
\text { Jordan, Bangladesh, Brunei, Iraq }\end{array}$ & $\begin{array}{l}\text { Cyprus, Georgia, Macedonia, Montene- } \\
\text { gro, Bosnia and Herzegovina, Moldova }\end{array}$ & $\begin{array}{l}\text { Tunisia, Egypt, } \\
\text { Algeria, Libya }\end{array}$ \\
\hline Risk zone & $\begin{array}{l}\text { Afghanistan, East Timor, Syria, } \\
\text { Yemen }\end{array}$ & Kosovo & \\
\hline
\end{tabular}

ACTIONS FOR THE DEVELOPMENT OF

\section{CHINA'S INVESTMENT STRATEGY IN THE "BELT AND ROAD" COUNTRIES}

(1) Considering the attractiveness of investment environment, it makes sense to apply the principle which states that while a "big country is important, the periphery is even more important." Government agencies, industry associations, large enterprises, and the relevant administrative authorities of the "Belt and Road" countries could combine their efforts to support basic science and technology, including the study of investment environment, and create a joint center for the study of investment sources [Li et al., 2015]. They could work together to increase the human capital and enhance exchange of investment, taking into account differences in local conditions, investment climate, and permissible loads on the environment.

(2) Based on the positive experience of the Shanghai Cooperation Organization in the creation of favorable conditions for businesses, regional organizations "moving outward" of the "Belt and Road" countries should coordinate economic policies to develop the institutions of multilateral cooperation, such as the China-ASEAN $(10+1)$, Asia-Pacific Economic Cooperation (APEC), Asia-Europe Meeting (ASEM), Asia Cooperation Dialogue (ACD), Conference on Interaction and Confidence-Building Measures in Asia
(CICA), China-Arab States Cooperation Forum, China-Gulf Cooperation Council (GCC) Strategic Dialogue, Greater Mekong Subregion Economic Cooperation Program (GMS-EOC), and Central Asia Regional Economic Cooperation (CAREC). It is necessary to strengthen the links between the regional organizations and to explore mechanisms for conflict resolution and reduction of investment risks.

(3) The Chinese government should actively promote entering into or renewing regional agreements with countries of potential investments on admittance and protection of investments and on insurance of legal rights and long-term development of companies with Chinese participation. Emphasis should be given to the creation of specific structures for collaborative development of institutions for continuous interaction and investment safeguards that promote sustainable economic and social development of the "Belt and Road".

(4) It is feasible to actively promote the study of inter-state differences in the legal field and training of highly qualified personnel to work in multinational investment companies. It is necessary to thoroughly study the investment legislation and other areas of social life in the countries targeted for investments, including culture, tradition, religion, and information about changes in the policy 
of the different countries, thus avoiding "blind" investment and assessing, in a timely manner, emerging risks.

(5) Investors need to strengthen cooperation with the appropriate government authorities of the countries targeted for investments, to determine and take into account the opinion and recommendation of the governments, and to strictly adhere to the laws of the host countries, thus ensuring ability of enterprises to establish relations with the governments and communities.

\section{ACKNOWLEDGEMENTS}

The study was financially supported within the framework of the key project of the Chinese Academy of Science "Belt and Road" (ZDRW-ZS-2016-6-5), Key Consulting Projects of the Institute of Strategic Consultation for science and technology of CAS (Y02015001), special research projects of China-ASEAN Innovation Center on regional development, Program of the Ministry of Education on the progress of scientists and creative teams (CW 201501).

\section{REFERENCES}

1. Chinese Encyclopedic Dictionary. (1999) Seventh Edition. Beijing: Zhongguo dabaike quanshu chubanshe, 5383. [in Chinese].

2. Goberman S., Shapiro D. (2002) Global foreign direct investment flows: The role of governance infrastructure. World Development. 30 (11): 1899-1919.

3. Jian S. Wang H.J., Li B.X. et al. (1987) Investment environment in China. Center for Sociological Research and Development Studies of China (PRC's State Council) and BeijingHong Kong Academic Exchange Centre. [in Chinese].

4. Kaufmann D., Kraay A., Zoido-Lobaton P. (1999) Aggregating governance indicators, Policy research working paper No. 2195. The World Bank.

5. Li J.J. (2004) Report on investment-environment study. Antropogeography. 19 (5): 34-39. [in Chinese].

6. Li Y., Li Z.H. Dong S.C. et al. (2015) Reflection on the adoption of the «Program for Fundamental Science and Technology Support of the «Silk Road Economic Belt.» Proceedings of the Chinese Academy of Sciences. 30 (1): 32-36. [in Chinese].

7. Li Y.N. (1993) The Great Market Economy Dictionary. Beijing: Xinhua chubanshe, 439. [in Chinese].

8. Litvak I.A., Banting P.M. (1973) A conceptual framework for international business arrangement In: Sethi S.P., Sheth J.N., eds. Multinational Business Operations: Marketing Management (Vol. 3). Pacific Palisades: Goodyear Publishing, 85-95.

9. Liu W.D. (2015) Scientific issues and scientific content of the "Belt and Road" strategy In: Progress in Geographical Science (Dili kexue jinzhan). 34 (5): 538-544. [in Chinese].

10. Robock S.H. (1971) Political risk: identification and assessment. Journal of World Business. (7-8): 6-20.

11. Stobaugh R.B. (1969) How to analyze foreign investment climate. Harvard Business Review, 48 (5): 100-109.

12. Vision and action plan to promote the joint creation of "The Silk Road Economic Belt" and "the 21 st-Century Maritime Silk Road. (2015) The National Reform Development Commission, the Ministry of Foreign Affairs, and the Ministry of Commerce of China. Beijing: Waijiao chubanshe. [in Chinese]. 
13. Wu Y.M. (2002) Creation of an index system for assessment of investment environment of Chinese regions and an integrated assessment method. Nandu xuetan, 22 (2): 109-113. [in Chinese].

Received on January $21^{\text {st }}, 2017$

Accepted on February $9^{\text {th }}, 2017$

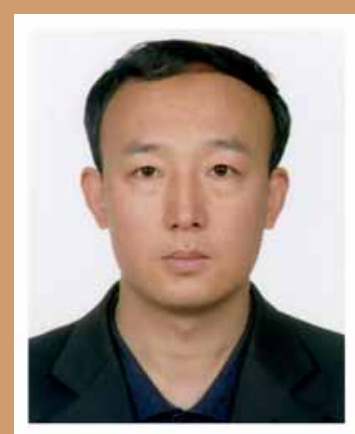

Li Yu is associate professor and master's supervisor at the Institute of Geographic Sciences and Natural Resources Research, Chinese Academy of Sciences, and Professor at the University of Chinese Academy of Sciences. He is also Secretary General of Regional Ecological Economics Committee of China Society for Ecological Economics. He was respectively honored with the awards of China Society of Natural Resources, Chinese Ministry of Land and Resources and Hebei Province. In recent years, he published more than 30 papers, and was the leading author of four important consulting reports for the government on regional sustainable development.

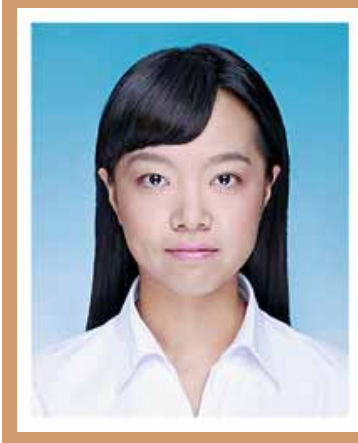

Zheng Ji is a research assistant in Institute of Geographic Sciences and Natural Resources Research, Chinese Academy of Sciences. Her research focuses on the resources and environment evaluation and low-carbon traffic. She has published 12 papers and participated in more than 10 research projects.

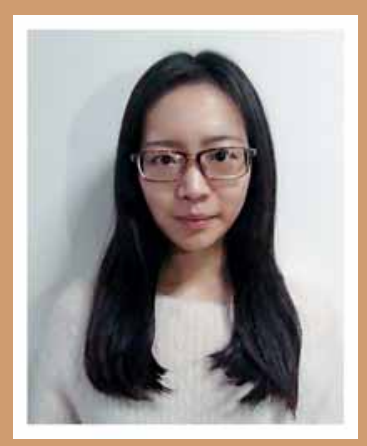

Jin Xueting is a master candidate of Institute of Geographic Sciences and Natural Resources Research, Chinese Academy of Sciences. Her research focuses on resource economic and lowcarbon city. She has published 2 papers and participated in more than 10 research projects. 


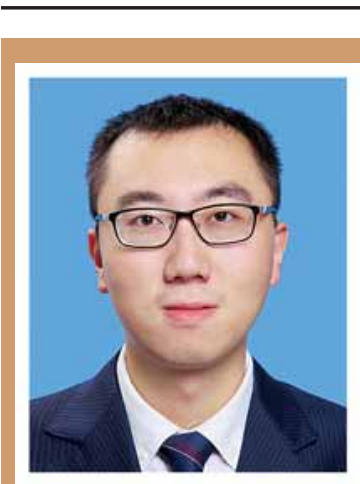

Wang Zhe is the expert of the International Scientist Union of "the Belt and Road Initiative", Ph.D. candidate of Institute of Geographic Sciences and Natural Resources Research, Chinese Academy of Sciences He focuses on regional ecological economics and cyclic economy. He joined in more than 10 national or provincial research projects and published more than 10 papers.

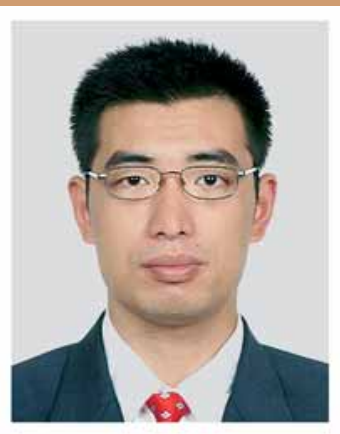

Li Zehong is an associate professor and master supervisor from Institute of Geographic Sciences and Natural Resources Research, CAS. He also is the Secretary-General of resources economy research committee of China's Society of natural resources and the Deputy Secretary General of the International Conference on Eco-environment and Sustainable Development of Silk Road Economy Zone. His mainly academy direction is in regional ecological economic system analysis and resource economics research. He has participated in and finished more than 20 research projects including national science and technology basic special project, National Natural Science Foundation Project and regional cooperation projects. He has published more than 50 papers.

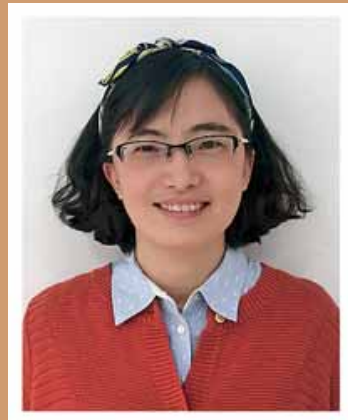

Zhao Minyan is a Ph.D. candidate of Institute of Geographic Sciences and Natural Resources Research, Chinese Academy of Sciences and an associate professor of Faculty of Ecotourism, Southwest Forestry University. Her research focuses on regional ecological economy, environmental interpretation and ecotourism. She is the first Chinese person certified as Interpretive Trainer of the National Association for Interpretation, USA. She had published 40 papers and participated in more than and 20 research projects.

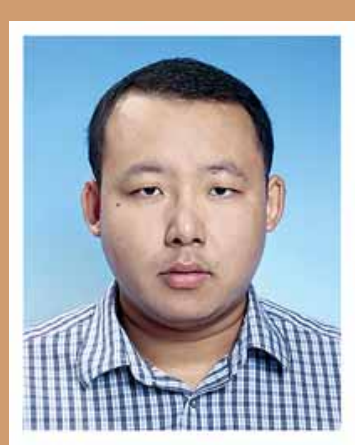

Huang Yongbin works at the School of Economics, Anhui University. His main areas of study are urban development and regional ecological economics. 


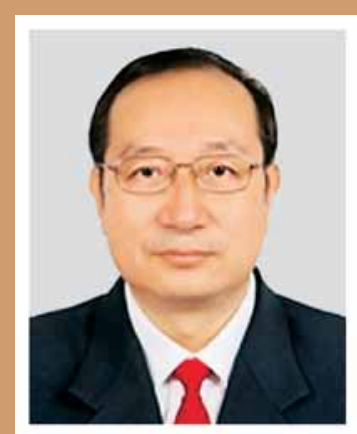

Dong Suocheng, Doctor of Sciences, is leading professor of Institute of Geographic Sciences and Natural Resources Research, Chinese Academy of Science. He is the Executive Chairman and Secretary General of the International Scientists Union of the Belt and Road Initiative; member of Russia and China Ecological Council. He also serves many renowned institutions of China Regional Ecological Economics Research and Planning Center; Resource Economics Research Center; Committee of Regional Ecological Economics; Committee of Resource Economics Research of China Natural Resources Society; Tourism Research and Planning \& Design Center, IGSNRR, CAS. He is vice president of Chinese Society of Ecological Economics; member of Green Industry Expert Committee of China, UNIDO. He focuses on theory and practice of regional eco-economics and resource economics, and put forth the ecological civilization construction modes, Chinese characteristic circular economy modes, eco-city modes and comprehensive tourism modes, which are widely implemented in many areas of China. He presided over more than 90 key research projects of National Natural Science Foundation of China, international cooperation, key research programs of the ministries and local governments, and obtained more than 14 awards. Nine important advisory reports wrote by professor Dong were adopted by the office of the State Council, which provided important scientific and technological supports for national socio-economic development decision making. He also dedicates to promote international cooperation among China, Russia and Mongolia. He is now in charge of the state key project of multi-disciplinary Scientific Expedition of RussiaMongolia-China international economic corridor funded by the Ministry of Science and Technology of P.R. China, from 2016 to 2021. He is the author of over 300 academic papers and books. 